\title{
NOTICE OF MEETING
}

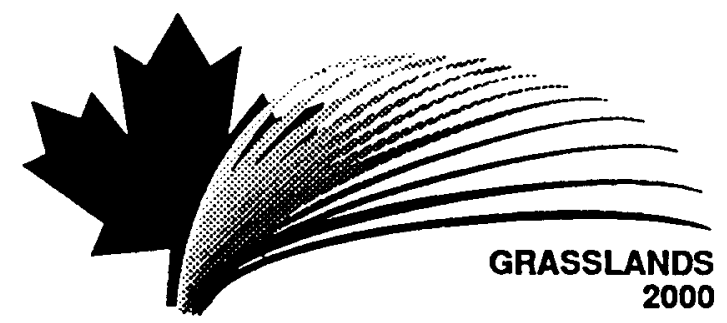

\section{International Grasslands Congress}

\author{
June 8-19, 1997
}

\section{Winnipeg, Manitoba}

\section{and}

\section{Saskatoon, Saskatchewan}

\section{Canada}

For more information contact:

International Grasslands Congress Office Box 4520, Station C

Calgary, Alberta

Canada T2T 5N3

Telephone: (403) 244-4487

Fax: (403) 244-2340 


\section{CALL FOR ABSTRACTS \\ 1997 ANNUAL MEETING OF THE INTERNATIONAL EMBRYO TRANSFER SOCIETY}

\section{2-14 January; Nice Acropolis, Nice, France}

Free communications will be presented as posters, abstracts of which will be published in the January, 1997 issue of THERIOGENOLOGY. Abstracts must be in English, and prepared according to THERIOGENOLOGY'S guidelines for direct offset reproduction; abstracts must adhere rigidly to the guidelines on format, paper quality, and font size. The abstract must report unpublished, original data, and contain objectives, experimental methods, results, and conclusions. Due to space restrictions, no one may be first author of more than one abstract or co-author of more than four abstracts. Each abstract will be subjected to rigorous scientific review by at least two referees. A signed commitment to present the data in the poster session at the annual conference is required. Students may enter their abstract in a competition sponsored by the IETS Foundation, and also are eligible to compete for three US\$500 travel awards. The Foundation also offers to scientists from developing countries a grant to be awarded competitively on specific merit and need, consisting of US\$1500 to be applied toward travel and lodging; registration fees will be deferred. Request details of eligibility, judging procedures, and prizes from the IETS office before preparing abstracts.

The firm deadline for receipt of the abstract (original and three photostatic copies) is 15 August 1996. Do not fold your abstract and please provide some stiff backing to protect the abstract during transit. Fax copies will not be accepted. They should be mailed (postmark deadline) by 1 August (outside Europe) or 10 August (within Europe) to:

Dr Steph J. Dieleman, 1997 IETS Programme Chairman

Department of Herd Health and Reproduction

Faculty of Veterinary Medicine

Utrecht University

Yalelaan 7

3584 CL Utrecht, The Netherlands

Telephone: +31 30253 1243; Fax: +31 302521887

E-mail: DIELEMAN@BDV.DGK.RUU.NL

Abstract forms and instructions as well as information about the student competition and travel awards may be obtained from:

Mr Carl Johnson

International Embryo Transfer Society

1111 N. Dunlap Ave., Savoy, IL 61874 USA

Telephone: +001/217-356-3182; Fax: +001/217-398-4119

Topics of the invited papers include regulation of follicular and oocyte maturation, epidemiology of diseases related to the use of embryo transfer, progress with new sources of genetic material in breeding, what determines sex in mammals, and intercellular communication between embryo and recipient. There will be discussion of endangered species, cryopreservation and embryo banking, application of new techniques, and international embryo movement in workshops. 
Illustrations. The same material should not normally be presented in tables and figures. Legends should be typed on a separate sheet.

a) Diagrams should be drawn in black ink, about twice the size of the finished block, on white paper or card, stout tracing paper or plastic film. Photographed diagrams are also accepted. Lettering inside the framework of the diagram should be avoided as far as possible but if unavoidable it should be included on a fly-leaf.

b) Photographs intended for half-tone reproduction should be on glossy paper. They will be accepted only if found necessary by the editors.

c) Colour plates are unlikely to be accepted unless the authors bear the cost.

Tables should be as simple and as few as possible. Each table should be typed on a separate sheet.

Abstract. Every paper should have a short abstract (not more than 250 words) complete in itself and understandable without reference to the paper. The abstract will be printed at the beginning of the paper and preferably should be in the format of unnumbered short paragraphs.

Keywords. Up to a maximum of five keywords selected from the CAB Thesaurus (1988) or from an equivalent reference volume should be listed at the end of the Abstract.

References. Only papers closely related to the author's work should be referred to; exhaustive lists should be avoided. References with three or more authors should be cited in the first on subsequent occasions with the first author in full followed by et al. (e.g. Smith, Jones and Brown: Smith et al.). References with two authors should be cited in full on all occasions. References should be given in full in the Reference list and it is the responsibility of authors to check for absolute accuracy in every detail of the reference.

Proofs are supplied once and must be returned corrected to the editors within 3 days. Only essential corrections should be made.

Reprints. Twenty-five reprints of each paper will be supplied free of charge to authors on request. Further copies may be purchased if the order is sent at the proof-stage.

Annual subscription is $£ 140.00$ (or $\$ 255.00$ in the USA and Canada) and the price for a single part is $£ 24.00$ (or $\$ 43.00$ ) net.

Abstracts of papers presented at British Society of Animal Science winter meeting are published as a separate section in the June issue of Animal Science.

Correspondence regarding subscriptions and sales (current and back numbers of the Journal) and any other enquiries, including those concerning copyright, should be addressed to: Durrant Periodicals, Winton Lea, Pencaitland, East Lothian, Scotland EH34 5AY.

Senior editor

T. L. J. Lawrence, University of Liverpool, UK

Editors

J. A. M. van Arendonk, University of Wageningen, The Netherlands

M. V. Dodson, Washington State University, USA

W. Haresign, University of Nottingham, UK

J. W. James, University of New South Wales, Australia

J. J. Kennelly, University of Alberta, Canada

I. J. Lean, Wye College, University of London, UK

K. Lundstrom, Swedish University of Agricultural Sciences, Sweden

C. S. Mayne, Agricultural Research Institute of Northern Ireland, Hillsborough, UK

C. A. Morgan, Scottish Agricultural College, Edinburgh, UK

P. J. Moughan, Massey University, New Zealand

J. D. Oldham, Scottish Agricultural College, Edinburgh, UK

E. Owen, University of Reading, UK

R. E. Short, US Department of Ágriculture, Montana, USA

A. J. F. Webster, University of Bristol, UK

I. D. Wood, University of Bristol, UK

J. A. Woolliams, Roslin Institute, Edinburgh, UK

Technical cutitors

Hilary Davies, Liverpool, UK

Carol Woolliams, Peebles, UK

Notes to users in the USA. The appearance of the fee codes in this journal indicates the copyright owner's consent that copies of the article may be made for personal or internal use on the following conditions. The copier must pay the stated per-copy fee through the Copyright Clearance Center, Inc., 21 Congress Street, Salem, Massachusetts 01970, USA, for copying beyond that permitted by sections 107 and 108 of the US Copyright Law. For territories outside North America, permission should be sought direct from the copyright holder. This consent does not extend to other kinds of copying, such as copying for general distribution, for advertizing and promotional purposes, for creating new collective works or for resale. 


\section{Contents}

Moorby, J. M., Dewhurst, R. J., Thomas, C. and Marsden, S.

The influence of dietary energy source and dietary protein level on milk protein concentration from dairy cows

Mayne, C. S. and Doherty, J. G.

The effect of fine grinding or sodium hydroxide treatment of wheat, offered as part of a concentrate supplement, on the performance of lactating dairy cows

Agnew, K. W., Mayne, C. S. and Doherty, J. G.

An examination of the effect of method and level of concentrate feeding on milk production in dairy cows offered a grass silage-based diet

Hatendi, P. R., Mulenga, F. M., Sibanda, S. and Ndlovu, P.

The effect of diet and frequency of watering on the performance of growing cattle given food at maintenance

Méndez, D. G., di Marco, O. N. and Corva, P. M.

Energy expenditure of cattle walking on a flat terrain

Di Marco, O. N., Aello, M. S. and Méndez, D. G.

Energy expenditure of cattle grazing on pastures of low and high availability

Finnerty, M., Enright, W. J., Prendiville, D. J., Spicer, L. J. and Roche, J. F.

The effect of different levels of gonadotropin-releasing hormone antibody titres on plasma hormone concentrations, sexual and aggressive behaviour, testis size and performance of bulls

Tregaskes, L. D., Broadbent, P. J., Hutchinson, J. S. M., Roden, J. A. and Dolman, D. F.

Attainment of puberty and response to superovulation in performance-tested Simmental heifers

Torii, S., Matsui, T. and Yano, $\mathbf{H}$.

Development of intermuscular fat in Wagyu beef cattle depends on adipogenic or antiadipogenic substances present in serum

Schrama, J. W., Heetkamp, M. J. W., Verstegen, M. W. A., Schouten, W. G. P., Veen, F. van der and Helmond, F. A.

Responses of young calves, on two levels of feeding, to transportation

Hughes, B. O., Hughes, G. S., Waddington, D. and Appleby, M. C.

Behavioural comparison of transgenic and control sheep: movement order, behaviour on pasture and in covered pens

Suttle, N. F., Brebner, J., McLean, K. and Hoeggel, F. U.

Failure of mineral supplementation to avert apparent sodium deficiency in lambs with abomasal parasitism

Dam, J. T. P. van, Heide, D. van der, Hel, W. van der, Ingh, T. S. G. A. M. van den, Verstegen, M. W. A., Wensing, T. and Zwart, D.

The effect of Trypanosoma vivax infection on energy and nitrogen metabolism and serum metabolites and hormones in West African Dwarf goats on different food intake levels

Yan, T., Offer, N. W. and Roberts, D. J.

The effects of dietary nitrogen sources and levels on rumen fermentation, nutrient degradation and digestion and rumen microbial activity by wether sheep given a high level of molasses

Lewis, R. M., Simm, G., Dingwall, W. S. and Murphy, S. V.

Selection for lean growth in terminal sire sheep to produce leaner crossbred progeny

Blasco, A., Gogué, J. and Bidanel, J. P.

Relationships between ovulation rate, prenatal survival and litter size in French Large White pigs

Archer, J. A. and Pitchford, W. S.

Phenotypic variation in residual food intake of mice at different ages and its relationship with efficiency of growth, maintenance and body composition

Mulley, R. C., English, A. W., Thompson, J. M., Butterfield, R. M. and Martin, P.

Growth and body composition of entire and castrated fallow bucks (Dama dama) treated with zeranol

Motta Ferreira, W., Fraga, M. J. and Carabaño, R.

Inclusion of grape pomace, in substitution for alfalfa hay, in diets for growing rabbits 